\title{
Health Protocol in Penataran Train during the COVID-19 Pandemic
}

\author{
Nur Aldi Firmansyah, Achmad Wicaksono, M. Ruslin Anwar \\ Civil Engineering Department, Faculty of Engineering, Universitas Brawijaya, Malang, \\ 65145, East Java, Indonesia \\ aldi68574@gmail.com
}

Received 01-06-2021; accepted 13-07-2021

\begin{abstract}
Penataran train decreased the number of passengers by $77.13 \%$ in April 2020 , which resulted in a reduction in travel frequency and change origin-destination during the COVID-19 pandemic. This study aims to determine the characteristics of the Penataran train passengers and obtain policy recommendations about service standards and travel requirements based on respondents' choices using descriptive statistics. Questionnaires were distributed to 417 Penataran train passengers during new adaptation period. This study indicates that the frequency of trips during the new adaptation period is lower than before the pandemic. Only $10.55 \%$ of respondents give the reason that the risk of transmitting COVID-19 on the Penataran train is lower than other transportation. The maximum seating capacity is reduced to $50 \%$ according to respondent's perceptions. Wearing a mask, keep a distance, and wearing long-sleeved clothing can still be carried out because they are considered necessary as requirements for passenger travel. The GeNose C19 test letter is not recommended to be used as a document requirement because most respondents with low income do not want additional costs.
\end{abstract}

Keywords: COVID-19 pandemic, Health protocol, New adaptation period, Penataran train

\section{Introduction}

COVID-19 is a contagious disease that attacks the human respiratory system and has become a major health threat to society. It is transmitted through direct contact, spread by coughing or sneezing from an infected person [1] [2]. In Indonesia, the spread of the coronavirus is very fast, from the first patient on March 2, 2020 [3], to reaching one and half million cases on March 29, 2021 [4], and now the cases are still increasing.

The government has taken mitigation to prevent infection and transmission of COVID-19, namely large-scale social restriction policy in several cities. Several activities have been limited in the implementation, such as schooling, working, social and cultural activities, and traveling [5]. This policy

Cite this as: Firmansyah, N.A., Wicaksono, A. \& Anwar, R. (2021). Health Protocol in Penataran Train during the COVID-19 Pandemic. Civil and Environmental Science Journal (Civense), 4(2), 163-172. doi:

https://doi.org/10.21776/ub.civense.2021.00402.6 
resulted in decreased mobility in various sectors. Of the 34 provinces in Indonesia, the highest decline in mobility at 25 provinces has occurred at the transport station. In contrast, residential areas show increased mobility during the new adaptation period [6]. It shows that people in Indonesia are still afraid to travel, especially when using public transportation. Many people may avoid public transport because it can be considered a breeding ground for the virus, and it is difficult to avoid contact with other passengers [7].

The Penataran Train is one of the trains affected by COVID-19. The decrease in the number of passengers reached 23.54\% in March 2020, 77.13\% in April 2020, and 7.10\% in May 2020 [8]. As a result, this train experienced a reduction in the frequency of travel and changes in origin-destination for three-step until finally, it entered a new adaptation period. At this time, the implementation of health protocols was strictly carried out, and reduced seating capacity as recommended physical distancing must also be fulfilled. To minimize the risk of spreading COVID-19 on trains, passengers must improve hand hygiene and use protective equipment such as face masks. In addition, the operator must also check passenger temperatures, clean seats using the disinfectant liquid, and adjust the distance between passengers to at least two seats [9].

The coronavirus outbreak (COVID-19) has not ended, but Indonesia's economy must continue, especially in the public transportation sector, one of which is rail transportation. The most important thing is to prepare the best scenario for train facilities and infrastructures that are humanist, clean, healthy, and safe by observing established health protocols. This study aims to determine the characteristics of the respondent of the Penataran train before the COVID-19 pandemic and the new adaptation period. In addition, policy recommendations related to service standards and travel requirements were given based on respondents' choices.

Table 1. Secondary Data from Several Institutions and Regulations

\begin{tabular}{|c|c|c|}
\hline No & Institutions or Regulations & Required Data \\
\hline 1 & $\begin{array}{l}\text { Indonesian Railways Company } \\
\text { Operational Area } 8 \text { Surabaya }\end{array}$ & $\begin{array}{l}\text { - Implementation of the COVID-19 health protocol } \\
\text { on the Penataran Train }\end{array}$ \\
\hline 2 & $\begin{array}{l}\text { Decree of Minister of Health of the } \\
\text { Republic of Indonesia No. } \\
\text { HK.01.07/MENKES/382/2020 }\end{array}$ & $\begin{array}{l}\text { - Health protocol policies in transportation modes for } \\
\text { operators, workers, and passengers }\end{array}$ \\
\hline 3 & $\begin{array}{l}\text { Regulation of Minister of } \\
\text { Transportation of the Republic of } \\
\text { Indonesia No. PM } 18 \text { and PM } 41 \text { of } \\
2020\end{array}$ & $\begin{array}{l}\text { - Transportation controls was carried out during } \\
\text { travel } \\
\text { - Limiting the number of passengers on each mode } \\
\text { of transportation }\end{array}$ \\
\hline 4 & $\begin{array}{l}\text { Circular Letter of Minister of } \\
\text { Transportation of the Republic of } \\
\text { Indonesia No. SE } 14 \text { and SE } 15 \text { of } \\
2020\end{array}$ & $\begin{array}{l}\text { - Limiting the number of passengers on local train } \\
\text { - Health protocol policies that must be implemented } \\
\text { by train passengers } \\
\text { - Health protocol facilities that must be provided by } \\
\text { the operator }\end{array}$ \\
\hline 5 & $\begin{array}{l}\text { Circular Letter of Minister of } \\
\text { Transportation of the Republic of } \\
\text { Indonesia No. SE } 27 \text { of } 2021\end{array}$ & $\begin{array}{l}\text { - Health protocol policies that must be implemented } \\
\text { by train passengers during travel } \\
\text { - Health requirement policies for local train } \\
\text { passengers }\end{array}$ \\
\hline 6 & $\begin{array}{l}\text { Circular Letter of the COVID-19 } \\
\text { Handling Task Force of the Republic } \\
\text { of Indonesia No. } 12 \text { of } 2021\end{array}$ & $\begin{array}{l}\text { - Health protocol policies that must be implemented } \\
\text { by passengers during travel } \\
\text { - Health requirement policies for domestic travelers } \\
\text { - Monitoring, controlling, and evaluating COVID-19 } \\
\text { health protocol policies on public transportation }\end{array}$ \\
\hline
\end{tabular}




\section{Research Methods}

The research location was conducted in the Surabaya Gubeng Station and Malang Station. In addition, this research was also conducted during the Penataran Train trip. The questionnaire was filled out online using the Google Form application. This research was held for four months, from January to April 2021.

Research respondents were passengers who had traveled using the Penataran Train during the COVID-19 pandemic, aged 17 to 65 years old. The number of samples in this study was 417 people. There are two sampling techniques used in this study, namely simple random sampling and incidental sampling [10].

The data collection methods are primary and secondary surveys. The primary survey conducted was field observation by directly observing the implementation of health protocols on the Penataran Train and questionnaire surveys by distributing questionnaires to passengers. The secondary survey was carried out by collecting data and information from several institutions and regulations, as shown in Table 1. The data analysis used descriptive statistic, which explain the characteristics and travel behavior of the respondents.

\section{Result and Discussion}

\subsection{Implementation of the COVID-19 Health Protocol Policy}

Regulators and operators are required to arrange the best scenario, which is called health protocol, to restore confidence and reduce the concern of passengers about the spread of the COVID-19 virus on trains. During the new adaptation period, the government has the task to make new regulations related to health protocols that must be completed on public transportation, while operators are required to complete and implement health protocols when operating their vehicles. Indonesia Railways Company, as the dominant operator of the railways in Indonesia, has implemented the COVID-19 health protocol policy, which follows the regulations of the Ministry of Health [11], the Ministry of Transportation [12] [13] [14] [15] [16], and the Task Force for the Acceleration of Handling COVID-19 [17]. Health protocols that have been implemented in the operation of the Penataran Train, such as:

1. the crew trains use personal protective equipment such as mask, face shield, and gloves;

2. the conductor and railway police check passengers' temperature and health every three hours;

3 . the conductor and railway police check passengers' health protocol every one hour;

4. on trip cleaning clean interior of the train with disinfectant liquid;

5. limiting seat capacity by putting cross signs on seats;

6. the operator provides hand sanitizers that are placed in easily visible spot;

7. the conductor instructs passengers to keep obeying health protocol via train audio;

8. the operator provides isolation space for passengers who have abnormal body temperature and health problems; and

9. travel requirements that passengers must fulfill, such as:

a. wearing a medical or three-ply mask;

b. keeping the distance according to the seat number; and

c. wearing a jacket or long sleeve clothes.

\subsection{Characteristics of Respondents during the COVID-19 Pandemic}

Figure 1-4 illustrates the respondents' characteristics based on age, high education level, occupation, and monthly income. Figure 1 explains that most respondents were 21-30 years old, with a percentage of $70.74 \%$. It proves the results of direct observations in the field that productive people dominated the passengers of the Penataran Train during the new adaptation period. Figure 2 explains that the respondents are dominated by passengers with senior high school level $(45.80 \%)$ and undergraduate (36.69\%). While the most occupations are students (35.49\%) and private employees (33.09\%), as shown in Figure 3. There is a correlation between age, high education level, and occupation. Two groups dominate respondents: respondents aged 21-30 years old who still have the status as a university student 
with the latest education senior high school and respondents aged 21-30 years who are private employees with an undergraduate education background. Figure 4 shows that most respondents' monthly income is below IDR 2,000,000 with $47.00 \%$. It is evidenced by the fact that some respondents are students who do have no income, only a monthly stipend from their parents.

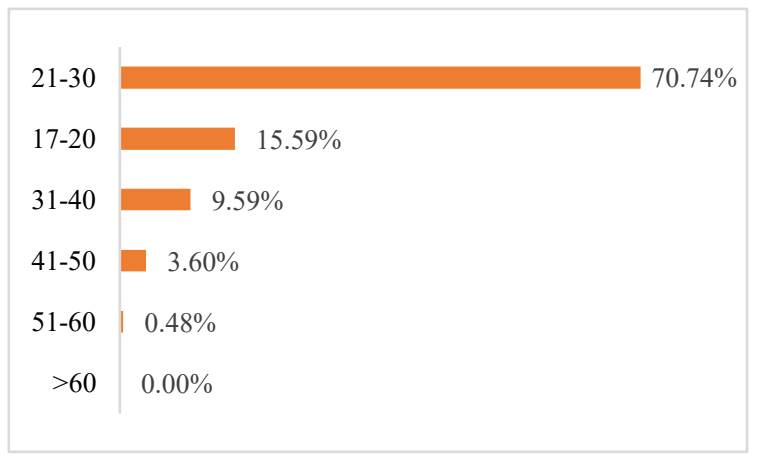

Figure 1. Respondent characteristics based on age.

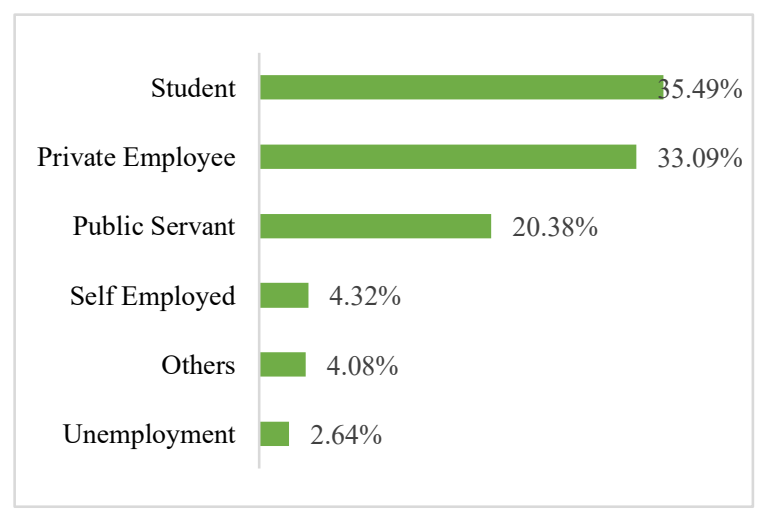

Figure 3. Respondent characteristics based on occupation.

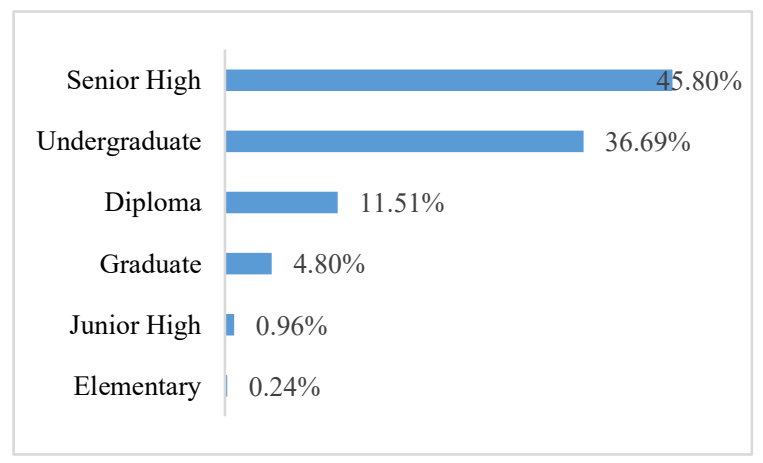

Figure 2. Respondent characteristics based on high education level.

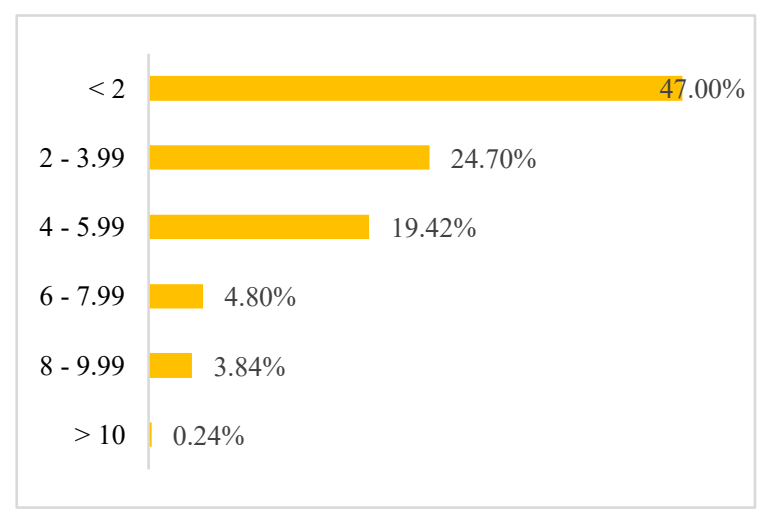

Figure 4. Respondent characteristics based on monthly income.

Based on Figure 5, the highest travel frequency before the pandemic and new adaptation period was 1-3 times a month. The frequency of trips during the new adaptation period is lower than before the pandemic; this is due to restrictions on out-of-home activities and restrictions on traveling out of town by the local government.

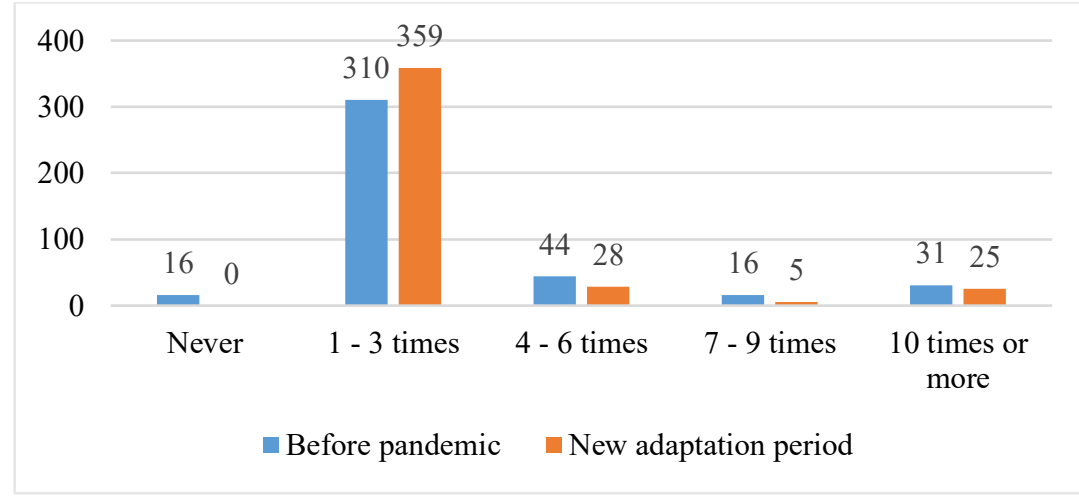

Figure 5. Comparison of travel frequency between before pandemic and new adaptation period. 
Figure 6 shows that most travel destinations before the pandemic and new adaptation period were social or family activities. As a local train, Penataran train has more stop stations than commercial trains, which are suitable for transportation to attend social activities or go to homecoming. During the COVID19 pandemic, the government suggested doing distance or online learning.

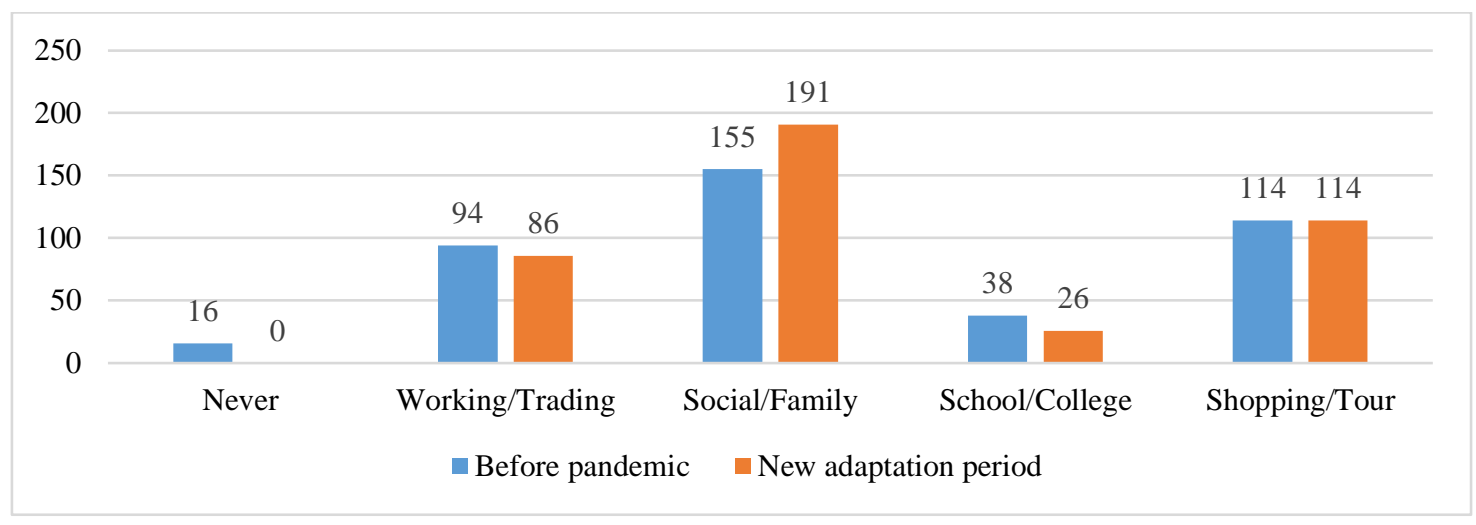

Figure 6. Comparison of travel frequency between before pandemic and new adaptation period.

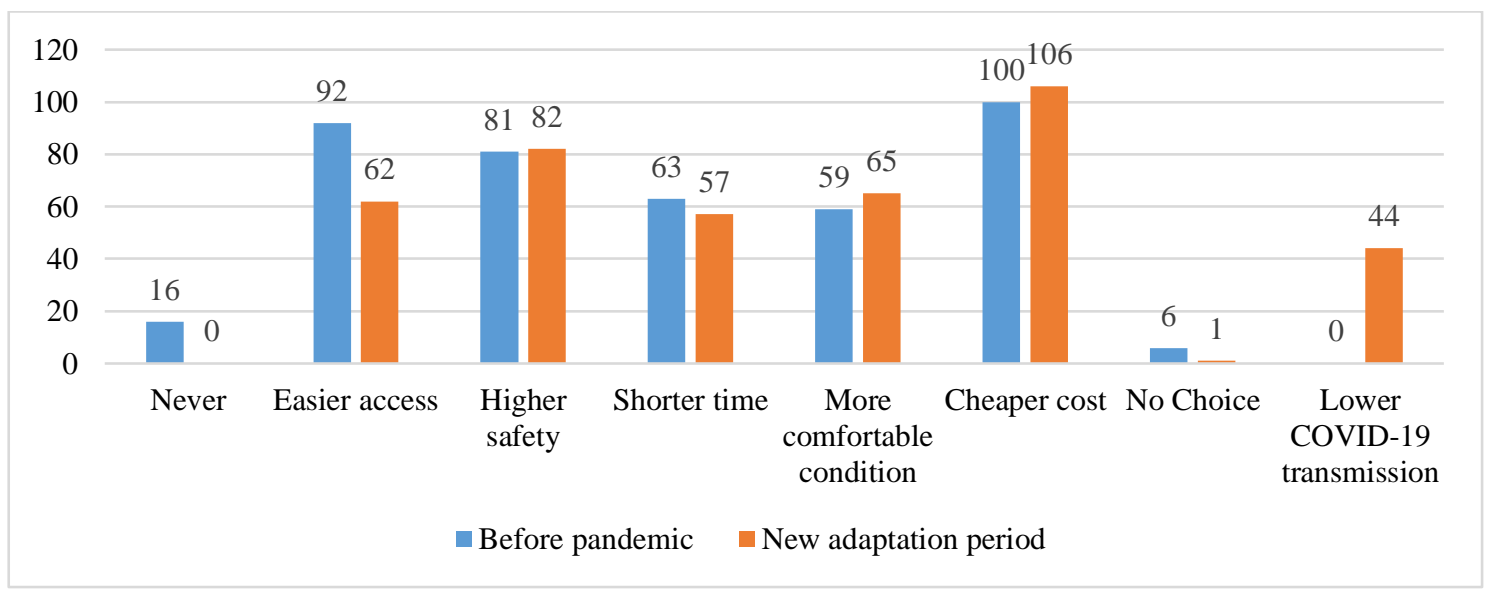

Figure 7. Comparison of the reason for using Penataran train before the pandemic and new adaptation period.

Based on Figure 7, the most reason for using the Penataran Train before the pandemic and new adaptation period is cheaper cost. The Penataran Train is one of the trains that get public service obligations from the government, making the price more affordable than other trains and other public transportations. The lack of activity during the COVID-19 pandemic impacts reduced income by some people; therefore, they choose cheap transportation to carry out their mobility. Only $10.55 \%$ of respondents gave the reason that the risk of transmitting COVID-19 on the Penataran Train is lower than other transportation, which means passengers feel that health protocols have not been appropriately implemented.

During the new adaptation period, the frequency of trips 1-3 times a month was dominated by passengers with social or family activities and followed by shopping or tour activities, as shown in Table 2. While the frequency of trips more than 3 times a month was dominated by working or trading activities. These results indicate that most respondents have followed local government recommendations regarding restrictions on activities outside the home. Activities carried out are only important and urgent, such as going to work and doing business. 
Table 2. Travel Frequency by purpose

\begin{tabular}{lccccc}
\hline & $\begin{array}{c}\text { Working/ } \\
\text { Trading }\end{array}$ & $\begin{array}{c}\text { School/ } \\
\text { College }\end{array}$ & $\begin{array}{c}\text { Social/ } \\
\text { Family }\end{array}$ & $\begin{array}{c}\text { Shopping/ } \\
\text { Tour }\end{array}$ & Total \\
\hline 1-3 times & 52 & 23 & 174 & 110 & 359 \\
\hline 4-6 times & 13 & 0 & 12 & 3 & 28 \\
\hline $7-9$ times & 3 & 1 & 1 & 0 & 5 \\
\hline 10 times or more & 18 & 2 & 4 & 1 & 25 \\
\hline \multicolumn{1}{c}{ Total } & 86 & 26 & 191 & 114 & 417 \\
\hline
\end{tabular}

Table 3 shows that cheaper cost becomes the strongest reason for respondents to choose the Penataran Train on the frequency of trips 1-9 times a month. Whereas on the frequency of trips ten times or more a month, some respondents considered that the Penataran Train had higher safety during the trip. Respondents who consider the Penataran Train as transportation with lower COVID-19 transmission travel only 1-3 times a month. It is indicated that this train cannot be regarded as safe from the spread of COVID-19.

Table 3. Travel Frequency by reason for choosing Penataran train

\begin{tabular}{ccccccccc}
\hline & $\begin{array}{c}\text { Easier } \\
\text { access }\end{array}$ & $\begin{array}{c}\text { Higher } \\
\text { safety }\end{array}$ & $\begin{array}{c}\text { Shorter } \\
\text { time }\end{array}$ & $\begin{array}{c}\text { More } \\
\text { comfortable } \\
\text { condition }\end{array}$ & $\begin{array}{c}\text { Cheaper } \\
\text { cost }\end{array}$ & $\begin{array}{c}\text { No } \\
\text { choice }\end{array}$ & $\begin{array}{c}\text { Lower } \\
\text { COVID-19 } \\
\text { transmission }\end{array}$ & Total \\
\hline 1-3 times & 53 & 67 & 47 & 61 & 90 & 1 & 40 & 359 \\
\hline 4-6 times & 3 & 6 & 4 & 3 & 8 & 0 & 4 & 28 \\
\hline 7-9 times & 1 & 1 & 1 & 0 & 2 & 0 & 0 & 5 \\
\hline $\begin{array}{l}10 \text { times or } \\
\text { more }\end{array}$ & 5 & 8 & 5 & 1 & 6 & 0 & 0 & 25 \\
\hline Total & 62 & 82 & 57 & 65 & 106 & 1 & 44 & 417 \\
\hline
\end{tabular}

\subsection{Respondents' Priorities on Service Standards and Travel Requirements}

Fifteen services must be completed on the Penataran Train according to transportation policies during the new adaptation period. Respondents must choose one service that is considered the most important during the trip, that the results are shown in Table 4 . In this figure, it can be seen that the seating capacity limitation was chosen by most respondents with a percentage of $48.44 \%$, followed by a physical distancing facility with signs on the floor $(11.27 \%)$ and cleaning trains with disinfectants liquid (10.31\%). From 15 services that have to be chosen by the respondents, 8 services have been implemented, and 7 others are not yet available on the Penataran Train. Distancing facilities with signs on the floor is the second most preferred service by respondents but are not yet available on the Penataran Train. Operators can add this service to the health protocol on the Penataran Train. The purpose of providing this service is to reduce the spread of the COVID-19 virus when passengers queue on the train.

The seating capacity of the Penataran Train is $70 \%$ of the total number of seats [14]. Before the COVID-19 pandemic, the seating capacity on each train was 159 passengers, while during the new adaptation period decreased to 74 passengers. Figure 8 shows the best maximum seating capacity according to the respondent's perception. As many as $54.20 \%$ of respondents chose a maximum capacity of $50 \%$ of the number of seats. Meanwhile, the maximum capacity of $70 \%$, which has been implemented in the Penataran train, is in second place with $23.74 \%$. Figure 9 is a recommended seat map if a maximum capacity of $50 \%$ is run on the Penataran Train. With this change in seating capacity, the operator can increase ticket prices, or the government can increase subsidies to cover the difference between train revenue and operating costs. 
Table 4. Most Important Passenger Service based on Respondent's Perception

\begin{tabular}{lc}
\hline \multicolumn{1}{c}{ Type of service } & Number of voters \\
\hline Seating capacity limitation & $48.44 \%$ \\
\hline Distancing facilities with signs on the floor & $11.27 \%$ \\
\hline Cleaning train with disinfectant liquid & $10.31 \%$ \\
\hline Checking the implementation of passenger health protocols & $9.35 \%$ \\
\hline Hand sanitizer facilities in the train & $4.32 \%$ \\
\hline Check passengers' body temperature and health & $4.32 \%$ \\
\hline Medical personnel during the trip & $2.64 \%$ \\
\hline Windows that open to increase air circulation from the outside & $2.40 \%$ \\
\hline Separation facility between passengers over 50 years old with other passengers & $1.92 \%$ \\
\hline Information about protocols to prevent the spread of COVID-19 via audio & $1.20 \%$ \\
\hline Selling personal protective equipment on the train & $0.96 \%$ \\
\hline Crew trains always use personal protective equipment & $0.96 \%$ \\
\hline Information about protocols to prevent the spread of COVID-19 via visual & $0.96 \%$ \\
\hline Isolation room on the trip & $0.72 \%$ \\
\hline Divider cover in the train dining room & $0.24 \%$ \\
\hline
\end{tabular}

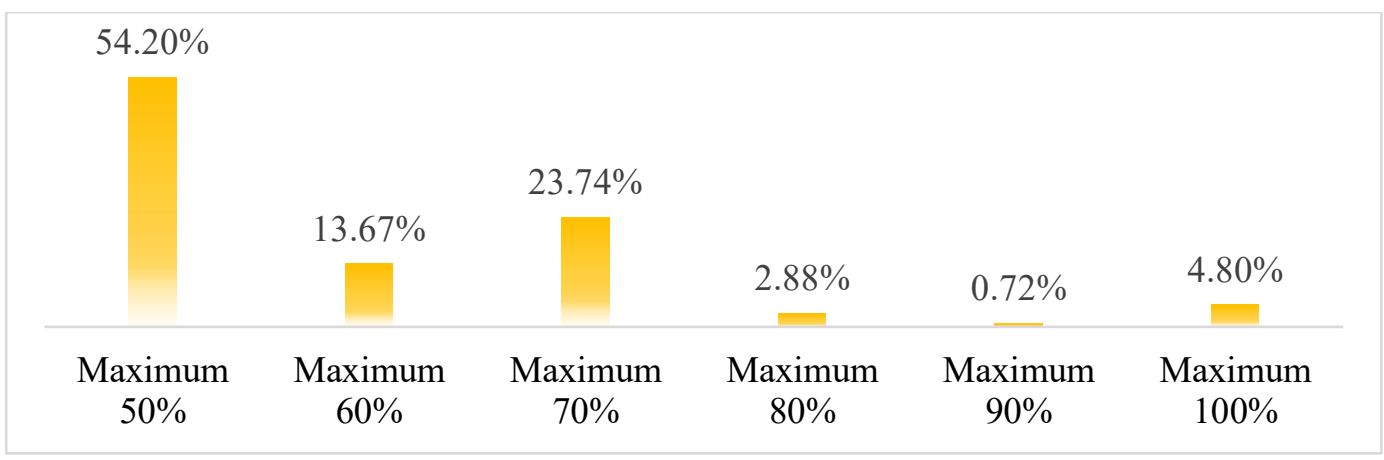

Figure 8. Maximum passenger capacity in Penataran train during the new adaptation period.

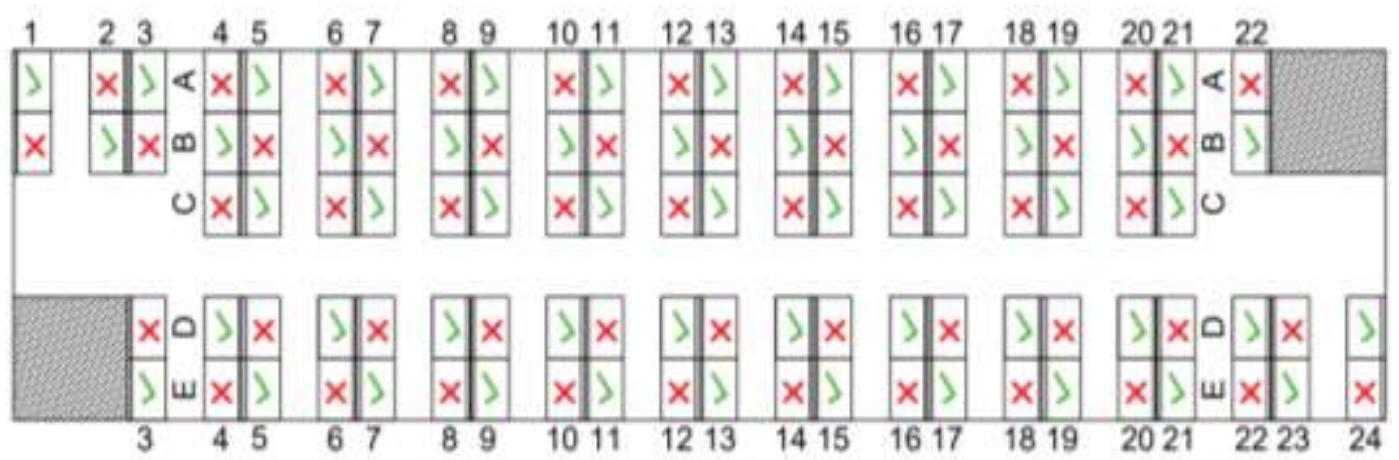

Figure 9. Map of train seats with a maximum capacity of $50 \%$.

During the new adaptation period, passengers are also required to carry out health protocols to prevent transmission of COVID-19. At this time, health protocols that passengers must carry out are 
wearing a mask, keeping the distance, and wearing long-sleeved clothing or a jacket. Document requirements such as rapid antigen / PCR / GeNose C19 test results are only required for long-distance train travel, not for local or agglomeration train travel [16] [17]. Figure 10 shows the respondents' perceptions regarding the travel requirements that must be fulfilled during this period. Three travel requirements were used as questions in the questionnaire. In addition, the GeNose C19 test was also questioned by respondents to measure the extent of the respondent's ability to comply with this requirement. The result shows that most respondents choose three health protocols that needed to be implemented. On the other hand, most respondents considered that the GeNose C19 test was not necessary to be a travel requirement.

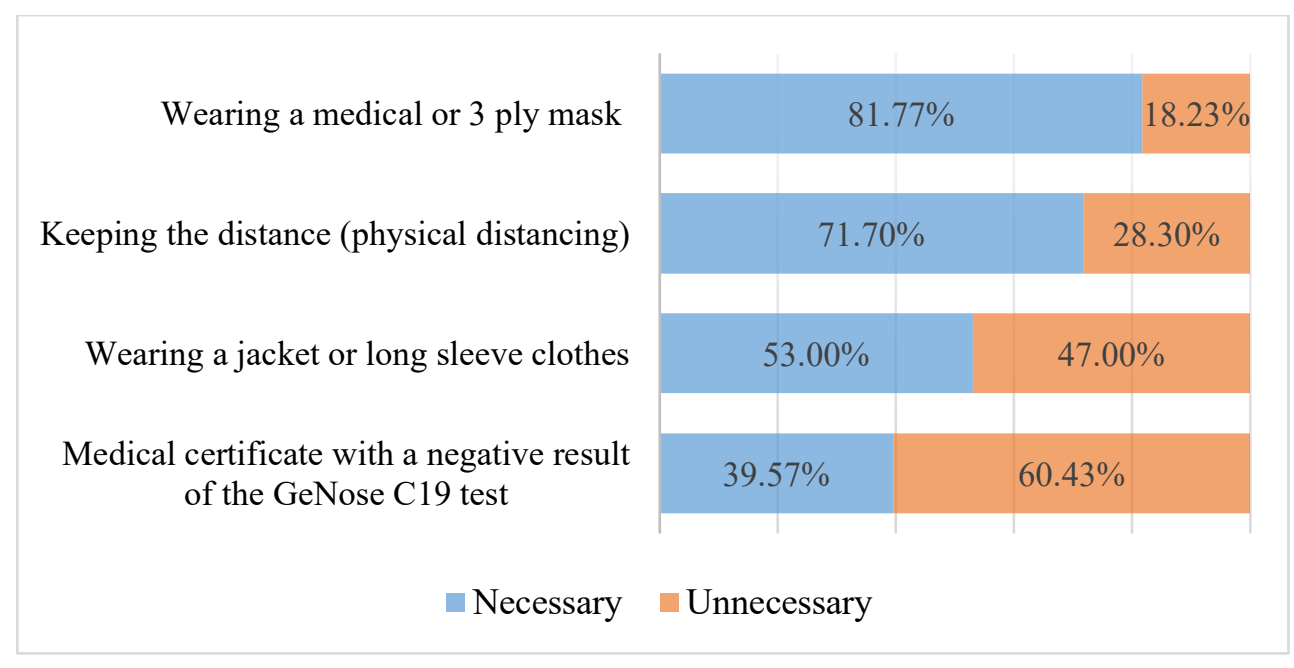

Figure 9. Passenger Travel Requirements in Penataran Train during New Adaptation Period based on Respondent's Perception.

Table 5 shows the correlation between respondents 'perceptions about the GeNose C19 test as a travel requirement and the respondents' monthly income. Most respondents with incomes below 2 million consider the GeNose C19 test unnecessary as a travel requirement. Respondents answered that it is necessary to have an average income of IDR 3,972,424, while respondents responded that it is unnecessary and has an average income of IDR 2,285,516. These results indicate that low-income passengers are unwilling to increase their travel costs to pay for the GeNose C19 test. In addition, these results reinforce that the most reason for using the Penataran Train is cheaper cost, which passengers need affordable public transportation during the COVID-19 pandemic. Therefore, the GeNose C19 test letter does not need to be used as a requirement for the Penataran train trip.

Table 5. Correlation between respondent's perceptions about GeNose C19 test and monthly income.

\begin{tabular}{cccc}
\hline & Necessary & Unnecessary & Total \\
\hline$<2$ million & 58 & 138 & 196 \\
\hline $2-3.99$ million & 32 & 71 & 103 \\
\hline $4-5.99$ million & 41 & 40 & 81 \\
\hline $6-7.99$ million & 18 & 2 & 20 \\
\hline $8-9.99$ million & 15 & 1 & 16 \\
\hline$>10$ million & 1 & 0 & 1 \\
\hline Total & 165 & 252 & 417 \\
\hline
\end{tabular}




\section{Conclusions}

Respondents were dominated by passengers aged 21-30 years (70.74\%), with the latest education being senior high school (45.80\%), being a student (35.49\%), and having monthly income less than IDR $2.000 .000(47.00 \%)$. The frequency of trips during the new adaptation period is lower than before the pandemic. Social or family activities are the most preferred travel purpose; on the other hand, school or college activities are the least chosen. The frequency of trips, ten times or more monthly, is dominated by passengers with the travel purpose of working or trading. The most preferred reason for using the Penataran Train is cheaper cost and is followed by higher safety. Respondents who considered the Penataran Train to be a place with lower COVID-19 transmission were only $10.55 \%$ of the respondents.

Health protocols on the Penataran Train must be added, such as distance facilities with signs on the floor for queuing passengers. Most respondents want the maximum seating capacity on each train to be $50 \%$; if this recommendation is implemented, the operator can increase its ticket price. The government can increase the subsidy to cover the difference between train revenues and operating costs. Wearing a mask, keeping the distance, and wearing long-sleeved clothing or a jacket are still considered necessary for the Penataran train trip. Most respondents with incomes below 2 million disagree if the GeNose C19 test letter was used as a document required for using the Penataran Train due to additional costs outside the ticket costs.

\section{References}

[1] H. a. B. S. Rothan, "The Epidemiology and Pathogenesis of Coronavirus Disease (COVID-19) outbreak," Autoimmunity, no. 109, 2020.

[2] S. Chavez, "Coronavirus Disease (COVID-19): A primer for emergency physicians," Emergency Medicine, 2020.

[3] M. H. Sukur, B. Kurniadi, Haris and R. Faradillahisari, "Penanganan Pelayanan Kesehatan Di Masa Akademi Covid-19 Dalam Perspektif Hukum Kesehatan," Inicio Legis, vol. I, no. 1, 2020.

[4] T. F. f. t. A. o. H. COVID-19, "The COVID-19 situation in Indonesia," 293 2021. [Online]. Available: https://covid19.go.id/. [Accessed 265 2021].

[5] M. o. H. R. o. Indonesia, "Regulation of the Minister of Health of the Republic of Indonesia No. 9/2020 about Large-Scale Social Restriction Guidelines For Accelerating the Handling of Coronavirus Disease 2019 (COVID-19)," Ministry of Health Republic of Indonesia, Jakarta, 2020.

[6] C.-1. C. R. Google, "COVID-19 Community Mobility Report," 24 January 2021. [Online]. Available: https://www.google.com/covid19/mobility/?hl=id. [Accessed 15 February 2021].

[7] J. D. Vos, "The effect if COVID-19 and subsequent social distancing on travel behavior," Transportation Research Interdisciplinary Perspectives, vol. 5, pp. 100121-100123, 2020.

[8] I. R. Company, Interviewee, The Volume Passanger of Penataran Train on January 2019 December 2020. [Interview]. 22 February 2021.

[9] M. Hu, H. Lin, J. Wang, C. Xu, A. J. Tatem, B. Meng, X. Zhang, Y. Liu, P. Wang, G. Wu, H. Xie and S. Lai, "Risk of Coronavirus Disease 2019 Transmission in Train Passengers: an Epidemiological and Modeling Study," Clinical Infectious Diseases, vol. 72, no. 4, pp. 604$10,2021$.

[10] Sugiyono, Metode Penelitian Kuantitatif, Kualitatif, dan Kombinasi (Mixed Methods), Bandung: Alfabeta, 2018.

[11] M. o. H. R. o. Indonesia, "Decree of the Minister of Health of the Republic of IndonesiaNo HK.01.07/MENKES/382/2020 about Protocol of Health for the Community in Place and 
Public Facilities for Prevention and Control of Coronavirus Disease 2019 (COVID-19)," The Ministry of Health Republic of Indonesia, Jakarta, 2020.

[12] M. o. T. R. o. Indonesia, "Regulation of the Minister of Transportation of the Republic of Indonesia No. 18/2020 about Transportation Control in order to prevent the spread of Corona Virus Disease 2019 (COVID-19)," The Ministry of Transportation Republic of Indonesia, Jakarta, 2020.

[13] M. o. T. R. o. Indonesia, "Regulation of the Minister of Transportation of the Republic of Indonesia No. 41/2020 on Changes to the Regulation of the Minister of Transportation of the Republic of Indonesia No. 18/2020 on Transportation Control in order to prevent the spread COVID-19," The Ministry of Transportation Republic of Indonesia, Jakarta, 2020.

[14] M. o. T. R. o. Indonesia, "Circular Letter No. 14/2020 on Guidelines and Technical Instructions for Rail Transportation in New Adaptation Period to Prevent the Spread of Coronavirus Disease 2019 (COVID-19)," The Ministry of Transportation Republic of Indonesia, Jakarta, 2020.

[15] M. o. T. R. o. Indonesia, "Amendment to the Circular Letter of The Minister of Transportation No. 14/2020 on Guidelines and Technical Instructions for Rail Transportation Control in New Adaptation Period to Prevent the Spread COVID-19," The Ministry of Transportation Republic of Indonesia, Jakarta, 2020.

[16] M. o. T. R. o. Indonesia, "Circular Letter No. SE 27/2021 on Instruction for Implementing People' Travel by Rail Transportation During the Pandemic Corona Virus Disease 2019 (COVID-19)," The Ministry of Transportation Republic of Indonesia, Jakarta, 2021.

[17] T. F. t. A. H. COVID-19, "Circular Letter No. 12/2021 on Provision for Travel of Domestic During the Pandemic Coronavirus Disease 2019 (COVID-19)," Government of Indonesia, Jakarta, 2021. 